\title{
The role of dopaminergic systems in the mediation of tonic immobility (animal hypnosis) in chickens
}

\author{
RICHARD H. ETTINGER and RICHARD W. THOMPSON \\ Western Washington University, Bellingham, Washington 98225
}

\begin{abstract}
To further investigate the role of the catecholamines in the mediation of tonic immobility (TI), three groups of 10 cockeral chicks were injected with distilled water or with 50 or $100 \mathrm{mg} / \mathrm{kg}$ of L-DOPA (L-3,4-Dihydroxyphenylalanine) before testing for TI duration. Results indicated that chicks injected with $100 \mathrm{mg} / \mathrm{kg}$ of L-DOPA had longer durations of TI than those injected with distilled water. These results suggest a mediating role of dopaminergic pathways in TI.
\end{abstract}

Tonic immobility (TI), which is typically induced by manually restraining and inverting the animal for a brief period, has been hypothesized to be an innate fear reaction (Gallup, 1974; Ratner \& Thompson, 1960). Recently, several investigators have attempted to identify physiological mechanisms involved in the mediation of TI. For example, the durations of TI increase in a dose-related manner following injections of epinephrine (Braud \& Ginsburg, 1973; Thompson, Scuderi, \& Boren, 1977). Similarly, injections of norepinephrine have been demonstrated to prolong TI durations (Thompson \& Joseph, Note 1).

Related research strongly suggests that norepinephrineand/or dopamine-containing neural pathways play critical roles in the mediation of several survival-related activities; for example, avoidance behaviors, aggression, stereotyped behaviors, eating, and self-stimulation (Seiden \& Dykstra, 1977). All of these behaviors, previously considered to be dependent upon the noradrenergic systems, are now considered dependent upon the integrity of the dopaminergic systems. The major role of dopaminergic systems is suggested to be modulating sensitivity to sensory input (Ungerstedt, 1974), while the role of the noradrenergic systems is believed to be that of regulating the dopaminergic systems during stressful circumstances (Antelman \& Caggiula, 1977; Antelman \& Szechtman, 1975; Yokel \& Wise, 1975).

Assuming that dopamine modulates sensitivity to sensory (e.g., tactile) input, increases in dopaminergic activity might be expected to facilitate the stereotyped feature of the immobility response. The present experiment was conducted to investigate the effects of L-DOPA, the metabolic precursor to dopamine, on TI

This report is based on a thesis submitted to the graduate school of Western Washington University by the first author in partial fulfillment of the requirements for the Master of Science degree. Richard H. Ettinger is now at the Department of Psychology, Washington State University, Pullman, Washington 99164. durations in chickens. It has been demonstrated that IP injections of L-DOPA attain a maximum stimulating effect on dopamine receptors within $1 \mathrm{~h}$, but do not increase noradrenergic activity in rats (Johnson, Loew, \& Vigouret, 1976). Similar results have been reported using chickens (Kobayashi \& Eiduson, 1970).

\section{METHOD}

\section{Subjects}

The subjects were 30 White Leghorn cockerel chicks obtained from a local hatchery 1 day after hatching and maintained in two commercial brooders with the temperature thermostatically controlled. The birds had continuous access to Purina chick feed and water throughout the experiment. An artificial daynight cycle provided light from 7:00 a.m. to 7:00 p.m.

\section{Apparatus and Procedure}

The testing apparatus consisted of a three-sided $(45 \mathrm{~cm}$ high $\times 30 \times 30 \mathrm{~cm}$ ) wooden induction box. To eliminate extraneous visual cues, the front of the box was covered with black burlap with a $12-\mathrm{cm}$ slit to allow access to the birds. Mounted above each chamber was a $25-\mathrm{W}$ incandescent bulb that provided lighting through frosted Plexiglas. A stopwatch was used to time the duration of the response.

To reduce the duration of $\mathrm{TI}$, all birds were habituated to handling and to the induction procedure. Starting at 10 days posthatch and continuing for 3 consecutive days, the birds were all given three TI inductions each day. Induction consisted of holding the birds upright for $5 \mathrm{sec}$, then turning the bird on its side and holding it down for an additional $15 \mathrm{sec}$. The response was terminated at $30 \mathrm{sec}$ by prodding the bird until it righted itself. On the 13 th posthatch day, the birds were haphazardly assigned to three groups of 10 birds per group. Group 1 birds received an IP injection of distilled water. Groups 2 and 3 received IP injections of 50 and $100 \mathrm{mg} / \mathrm{kg}$ of L-DOPA, respectively, dissolved in distilled water. All solutions were adjusted so that each animal received a volume of $1 \mathrm{cc} / \mathrm{kg}$. Following the injection, each bird was individually placed in a holding box for $1 \mathrm{~h}$ and was then tested for TI duration. Tonic immobility was timed from induction until the bird righted itself or $900 \mathrm{sec}$ had elapsed. Birds failing to remain down for $5 \mathrm{sec}$ were reinduced, using the same procedure, for up to five inductions or until they remained down for at least 5 sec. If a bird failed to remain down after the fifth induction, it was given a time of zero. 


\section{RESULTS AND DISCUSSION}

As predicted, injections of L-DOPA significantly increased TI durations $[\mathrm{F}(2,27)=11.74, \mathrm{p}<.001]$. The means and standard deviations for the three groups were: Group 1, mean $=133.8, \mathrm{SD}=103.4$; Group 2, mean $=95.1, \mathrm{SD}=83.4 ;$ and Group 3 , mean $=506.6$, $\mathrm{SD}=338.2$. Using Tukey's post hoc analysis, the difference between Group 1 (vehicle control) and Group 3 $(100 \mathrm{mg} / \mathrm{kg}$ L-DOPA) was significant $[\mathrm{T}(2,27)=5.62$, $\mathrm{p}<.01]$, but the difference between Groups 1 and 2 ( $50 \mathrm{mg} / \mathrm{kg}$ L-DOPA) was not. There were no significant differences in the number of inductions among groups.

These results strongly suggest a role for the dopaminergic systems in the mediation of TI. The increase in TI duration following L-DOPA injections is similar to increases observed following injections of norepinephrine (Thompson \& Joseph, Note 1). As stated previously, injections of norepinephrine may act to facilitate dopamine activity during stressful circumstances (Antelman \& Caggiula, 1977); therefore, the effect of norepinephrine injections on TI duration may be an indirect one.

It is noteworthy that the results of this experiment are inconsistent with those reported by Wallnau and Gallup (1977) that injections of L-DOPA had no effect on TI durations. One possible explanation for this inconsistency is that Wallnau and Gallup (1977) tested their birds 30 min following IP injections of L-DOPA. In the present study, birds were tested $1 \mathrm{~h}$ following injections, a time delay suggested to coincide with the maximum stimulating effect of L-DOPA on dopaminergic neurons (Johnson et al., 1976).

\section{REFERENCE NOTE}

1. Thompson, R. W., \& Joseph, S. Personal communication, February 1977.

\section{REFERENCES}

Antelman, S. M., \& Caggiula, A. R. Norepinephrinedopamine interactions and behavior. Science, 1977, 195, 646-653.

Antelman, S. M., \& Szechtman, H. Tail pinch induces eating in sated rats which appears to depend on nigrostriatal dopamine. Science, 1975, 189, 731-733.

BraUd, W. G., \& GinsBURG, H. J. Effect of administration of adrenalin on immobility reaction in domestic fowl. Journal of Comparative and Physiological Psychology, $1973,83,124-127$.

Gallup, G. G., JR. Animal hypnosis: Factual status of a fictional concept. Psychological Bulletin, 1974, 81, 836-853.

Johnson, A. M., Loew, D. M., \& Vigouret, J. M. Stimulant properties of bromocriptine on central dopamine receptors in comparison to apromorphine, (+)-amphetamine, and 1-dopa. British Journal of Pharmacology, 1976, 56, 59-68.

Koвayashi, K., \& Eiduson, S. Norepinephrine and dopamine in the developing chick brain. Developmental Psychobiology, 1970, 3, 13-34.

Ratner, S. C., \& Thompson, R. W. Immobility reactions (fear) of domestic fowl as a function of age and prior experience. Animal Behaviour, 1960, 8, 186-191.

Seiden, L. S., \& Dykstra, L. A. Psychopharmacology: A biochemical and behavioral approach. New York: Van Nostrand Reinhold, 1977.

Thompson, R. W., Scuderi, R., \& Boren, J. The effect of epinephrine on tonic immobility (animal hypnosis) in chickens. Bulletin of the Psychonomic Society, 1977, 9, 409-410.

UNGERSTEDT, U. Brain dopamine neurons and behavior. In F. O. Schmitt \& F. G. Worden (Eds.), The neurosciences: Third study program. Cambridge, Mass: MIT Press, 1974.

Wallnau, L. G., \& Gallup, G. D., JR. A serotonergic, midbrain-raphe model of tonic immobility. Biobehavioral Reviews, 1977, 1, 35-43.

YoKel, R. A., \& WISE, R. A. Increased lever pressing for amphetamine after pimozide in rats: Implications for a dopamine theory of reward. Science, 1975, 187, 547-548. 